\title{
Narcissism CEOs and Earning Management in Islamic Bank Evidence in Indonesia
}

\author{
Nisrina Savitri ${ }^{1}$, Dodik Siswantoro ${ }^{2}$ \\ \{Nisrinasavitri61@gmail.com ${ }^{1}$, Kidod25@gmail.com² \\ Department of Accounting, Universitas Indonesia ${ }^{1}$, Department of Accounting, Universitas Indonesia ${ }^{2}$
}

\begin{abstract}
This study examines relationship between psychological aspects of CEOs in Islamic Banking to earnings management, psychological aspects related to narcissism CEO. Based on the upper echelon theory, this study picks up the notion that narcissistic CEOs take advantage of accounting choices to enhance their firms and inherently their own personal track records. CEO considered parties related to the company's strategy and decision making, specifically for loan loss provision that represents earning management in the bank industry. Limited research in Islamic area especially in Islamic bank, which explain the psychological aspect from CEO. This study uses a sample of Islamic Banking in Indonesia 2014-2018, which is to measure CEO narcissism by using a photo size of CEO from the annual report, measurement of earnings management using loan loss provision. This study found evidence that there is no relationship between the psychological features of the CEO on earnings management in Islamic Bank.
\end{abstract}

Keywords: Narcissism CEO, Earning Management, Loan Loss Provision, Islamic Bank.

\section{Introduction}

Islamic banking operates under Islamic law, where there are restrictions on practices that contain garar (uncertainty), transactions using prohibited goods, and practices that are not in accordance with ethics and moral values. Nevertheless, Islamic banking is actually the same as other institutions where they also face problems of asymmetric information and conflicts of interest [1], which will lead to opportunistic behavior namely earnings management that is contrary to Islamic values.

Earnings management is a practice in which company management makes various discretions by utilizing various accounting options that can influence the interpretation of users of financial statements and also related to management efforts to provide desired information related to the company's future profit prospects, and often this discretionary action is used by parties management for personal interests related to compensation and their status in the company. According to The National Commission on Financial Reporting concluded that earnings management practices can mislead users of financial statements and often lead to more serious irregularities and fraudulent financial statements. It can be concluded that earnings management practices become a very important ethical problem faced by the accounting profession.

Based on Upper echelon theory the role of the CEO as the most important party in the company that determines various strategies and decisions in the company, as well as research by (Ban and Park 2017, Petenko et al 2016) states that the company's operational performance is significantly affected by the actions of the CEO giving us conclusions about the importance of the CEO's position in various corporate strategic actions, this also relates to earnings quality reflecting the decision-making and strategy chosen by the CEO which is influenced by the characteristics of the CEO primarily related to psychological aspects of values and personalities that influence decision making [2].

One psychological aspect related to CEO that significantly influences CEO decision-making behavior and company outcomes is narcissism This opinion is also supported by research by [3] which states the nature of CEO narcissism has significant implications for strategy and decision making. Recent research has shown considerable interest in personality characteristics that are broadly defined as positive self-regard, core self-evaluation, hubris, over-evidence and narcissism (Kim et al 2018) and [2] states that taking measurements related to aspects of personality or personality trait is something that is not easy, but [4] confirms that despite the challenges in measuring psychological characteristics, the implications of how they view themselves as executives and how aspects This psychological influence on various company outcomes is very important to study. Currently narcissism has been accepted as a personality trait shared by all individuals [5]. Thus, narcissism has attracted the 
attention of researchers and the public in general, so that several studies have used narcissism as a key characteristic in explaining the behavior of CEOs and their impact on company outcomes [6].

Specifically in the [2] stated that CEO narcissism is a personality that will affect the profit quality of the company, where a narcissistic CEO tries to display the company's financial condition as best as a reflection of its performance to be declared good by utilizing various accounting options existing, narcissistic CEOs are likely to commit greater fraud [7] and the possibility of material misstatement on financial statements. Previous studies have shown that there is a positive relationship between CEO narcissism and earnings management [8]. The research provides evidence that income is decreasing, where narcissistic CEOs are not only trying to influence stakeholder perceptions to the company's current performance, but also related to future income.

Research related to the relationship between governance that focuses on CEO or BOD issues on earnings management mostly discusses aspects related to demographics, such as: diversity, tenure, BOD composition, gender, and number of meetings. It can be concluded that there is still limited literature that examines the causes of earnings management which results in low quality earnings which is also caused by psychological factors or personality of the CEO, and the absence of literature on Islamic banking that considers aspects of CEO behavior as an element that affects earnings management, this study deemed important to do in Islamic banking considering Islamic banking also faces the same problems as conventional banking illustrated from several cases of Islamic banking in recent years, and based on research conducted by [9] states that the banking industry is often involved in earnings management activities, and this is of particular concern given that in the event of manipulation of financial statements and fraud, not only stakeholders and shareholders in general are disadvantaged, but also customers who entrust their funds to banks that will be highly fish if something bad happens to the bank.

\section{Literature Review and Framework}

\section{Upper Echelon Theory}

The theory states that the characteristics that exist in top management will directly affect the outcome in the company, where top management is a strategic decision maker and determinant of corporate strategy. the characteristics of the top leadership (upper echelon) greatly color the direction or choice of strategy (strategic choice) them, and ultimately determine organizational performance. This is certainly somewhat different from the understanding at that time, which placed managers no more merely as administrative managers, the management of the leadership strategy itself emerged only recently, which was previously called business administration. That is, aspects related to company leadership that had escaped the attention of academics, began to be raised by Hambrick and Mason. The CEO plays an important role in strategic decision making and resource allocation. Hambrick and Mason, through Upper Echelon Theory, state that the strategies chosen by leaders are a reflection of their values and cognitive abilities. This theory also shows that age, experience, education, social background, economic conditions, and the characteristics of the group where they are, are filters when they digest, analyze, and try to understand the anatomy of a problem. This determines their ability to interpret complex situations and in what way the situation must be managed. The upper echelon theory helps explain that leaders, influenced by their ability of knowledge, beliefs, and individual characteristics, have varied abilities to respond to crises that occur around them.

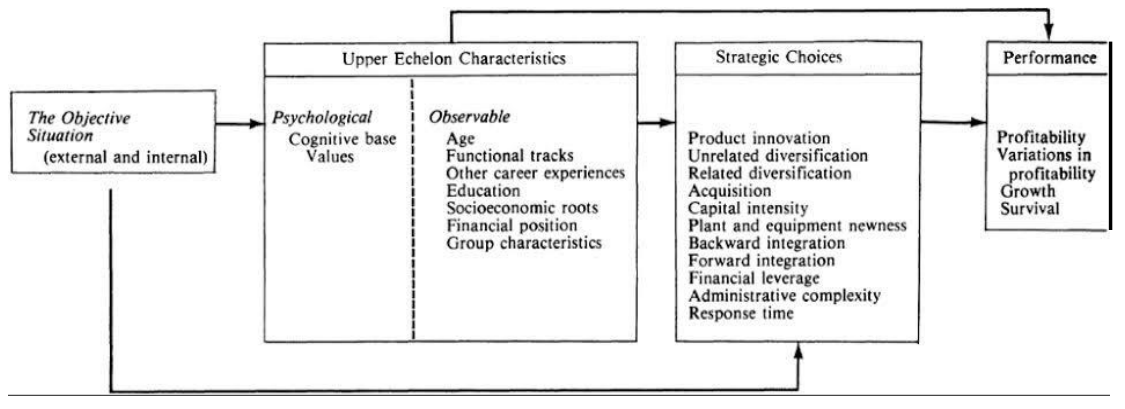

Fig .1. Upper Echelon Theory 


\section{Narcisism CEO}

Narcissistic or Narcisstic Personality Disorder according to the book Diagnostic and Statistical Manual of Mental Disorder (DSM) is a disorder of personality function (both self and interpersonal relationships) and is characterized by the presence of pathological traits of personality. Narcissism research in the context of accounting is relatively new. Narcissism research in the context of accounting was initiated by [6] They analyze the effects of CEO narcissism on corporate investment strategies that tend to be brave and high risk. His research inspired various further researchers, [8] who examined the auditor's response to narcissistic CEOs. Other research on narcissism in accounting found that companies led by narcissistic CEOs tended to publish misstated financial statements [32], undertook real earnings management [8] carried out tax sheltering, and aggressive in the acquisition process. Other research shows that CEO narcissism influences the quality of a company's financial statements, which is identical with the tendency to conduct earnings management, weak internal control, delays in recognition of earnings, and probability of restatements.

\section{Hypothesis}

Earnings management also occurs in Islamic banking, although on a smaller scale than conventional banking. Islamic banking is built based on Islamic principles and law which does not accept cheating and various unethical behaviors that cause harm to other parties [10]. However, the cases involving Islamic banks lately are inseparable from the problem of asymmetric information as faced by conventional banking.

Related to earnings management issues which are the outcomes of the company, the role of the CEO is something that deserves attention, CEO is the party who has the capacity to determine company outcomes, and accounting research related to earnings management has made the characteristics of the CEO be a variable that affects earnings management in the company. According to the theory of the Upper Echelon characteristics that exist in the CEO contribute a large influence in a variety of decisions, narcissism is one psychological aspect that significantly influences the various CEO decisions and company outcomes (Kim et al, 2018). The CEO is a leader who influences the organization, so that his personality will also affect the organization. One of the characteristics of a CEO described in the Upper Echelon Theory is related to psychological / personality aspects. This is supported by several previous studies [11] which states that CEO narcissism has a significant influence on earnings management in a company.

Excessive optimism about future performance by the CEO will lead to CEO behavior by utilizing existing accounting options for earnings manipulation aimed at hoarding future profits. Supporting the previous idea found evidence that earnings management that reduces income is used at a certain point of time, for example at the turn of the CEO, where the new CEO makes the situation as if a decline in performance or earnings that occur due to lack of performance of the previous CEO. It can be concluded that accounting choices made by narcissistic CEOs are driven by personal interests, so that it can be seen that there is a negative relationship between CEO narcissism with earnings quality or the positive relationship of CEO narcissism with earnings management. Previous research by [11], [33] stated that narcissistic CEOs tended to increase reported earnings.

The existence of myopia which gives negative long-term results. This relates to the desire of the CEO to be admired so they try to show an increase in income by utilizing various accounting options. These narcissistic CEOs will strive to maintain their position and try to build future income reserves through earning. Based on the explanation above, the first hypothesis that was built for this study is:

H1: CEO narcissism has a positive effect on earnings management in Islamic banking.

\section{Data and Methods}

\section{CEO Narcisism Measure}

Superiority photo of CEO

The company's annual report provides an opportunity for the CEO to report company's progress and prospects and present themselves as leaders of the company. Although CEO photos are a standard feature of the annual report, they are not universal or uniform. Discussions conducted by [6] with several company executives show that CEOs are very concerned about the content and design of annual reports, and they have strong opinions and control over how they themselves are described in the annual report. This is evidenced by data related to CEO photos in this study which showed that $63.41 \%$ of CEO turnover in a company was followed by changes in the 
size of the CEO photo in the annual report. The narcissistic CEO will look for a lot of visibility in the annual report, one of which aims to show that he occupies an important position in the company. Data related to the superiority of this CEO photo were obtained through each company's annual report [6] rank these indicators, which are presented in table 1 below

Table 1. Scoring of Nrcisissm CEO.

\begin{tabular}{lll}
\hline No & Explanation & Point \\
\hline 1 & $\begin{array}{l}\text { If the CEO photo stands } \\
\text { alone and is more than half } \\
\text { a page }\end{array}$ & 3 \\
& $\begin{array}{l}\text { If the CEO photo stands } \\
\text { alone and occupies less } \\
\text { than half a page }\end{array}$ & \\
& $\begin{array}{l}\text { If the CEO is photographed } \\
\text { with one or more other } \\
\text { boards of directors } \\
\text { No Photo of CEO }\end{array}$ & 2 \\
\hline
\end{tabular}

\section{Earning Management}

The dependent variable used in this study is earnings management. The measurement of earnings management aims to examine the relationship between CEO narcissism and DPS Education background on earnings management in Islamic banks, following the approaches taken by [1].This research uses a two stage approach. In the first stage, use specific accruals to measure earnings management in Islamic banks. More specifically, use a loan allowance (Loan Loss Provision). LLP consists of two components, namely discretionary and nondiscretionary. To determine the discretionary and non-discretionary components, the following equation is formed:

$$
L L P=\text { Non diskresionari } L L P+\text { Diskresionari } L L P
$$

Like [4] research, the Non-Discretionary Loan Loss Provision (NDLLP) component is measured using a series of variables including the initial Non Performing Loans (NPL) balance, changes in NPL and changes in total loans. Then, the model equation is as follows:

$$
L L P \text { it }=\beta 0+\beta 1 \quad N P L \text { it }-1+\beta 2 \quad \Delta N P L \text { it }+\beta 3 \quad \Delta T L \text { it }+\varepsilon \text { it }
$$

Then, model 2 is performed a regression test to get the constants and coefficients of each variable. After a regression test, the constants and coefficients $\left(\beta 0^{\wedge}, \beta 1^{\wedge}, \beta 2^{\wedge}, \beta 3^{\wedge}\right)$ are obtained. Then, using these constants and coefficients, the non-discretionary component of LLP can be calculated, namely the Non Discretionary Loan Loss Provision (NDLLP). So that the model 3 is formed as follows:

$$
N D L L P=\beta+\beta 1^{\wedge} N P L+\beta 2 \Delta N P L+\beta 3 \Delta T L+\varepsilon
$$

Finally, the discretionary component of LLP can be calculated through the difference between total LLP and estimated NDLLP. So the estimation of the equation is as follows:

$$
D L L P=L L P-\left[\hat{\beta}^{\wedge}+\hat{\beta}^{\wedge} N P L+\hat{\beta}^{\wedge} \Delta N P L+\hat{\beta}^{\wedge} \Delta T L\right]
$$




\section{Research Model}

By using quantitative methods with the type of combined data between time series (2013-2017) and cross section, the research uses panel data types. After going through several stages to calculate earnings management, the equation using the dependent and independent variables is based on the following hypothesis:

$D L L P_{\mathrm{it}}=\beta_{0}+\beta_{1} \mathrm{CEON}_{i t}++\beta 2$ Lev it $\beta{ }_{3}$Firmsage $_{i t}+\beta_{4}$ Size $+\beta_{5}$ CEOten $_{i t}+\beta_{6}$ CEOage $_{i t}+\beta{ }_{7}$ CEOgen $_{i t}$

$+\varepsilon_{i t}$

Dimana:

a. $\quad D L L P$

: Diskresionari provisi for loan, Murabaha, Musharaka, Mudarabah it investment in

bank i for year $\mathrm{t}$

b. CEON

: narcissism CEO

c. SIZE it

: logaritma natural sum asset bank $\mathrm{i}$ in year $\mathrm{t}$

d. Firms Age

: Age of firm, one plus natural logarithma from tenure of firm

e. Lev

: Leverage (debt to asset)

f. CEO Ten

: Tenure CEO, logarithma of tenure CEO

g. $\quad$ CEO Age

: Age of CEO, in years

h. CEO Gend

: Gender of CEO, dummy 1

\section{RESEARCH RESULT AND DISCUSSION}

This research uses panel data, and data processing is carried out through stat 13. From the results of descriptive statistics, it can be explained that 40 observations were made, 10 banks in the period 4 2015-2018.

Tabel 2.1 Descriptive Statistic

\begin{tabular}{r|rrrrr} 
Variable & Obs & Mean & Std. Dev & Min & Max \\
\hline LLPTotalPr d & 40 & -18176 & $2.21 \mathrm{e}+12$ & $-2.59 \mathrm{e}+12$ & $7.63 \mathrm{e}+12$ \\
CE0Photo & 40 & 4.3 & .8533494 & 3 & 5 \\
CE0age & 40 & 52.525 & 4.56288 & 40 & 61 \\
CE0tenure & 40 & 2.25 & 2.109198 & 0 & 8 \\
CE0gender & 40 & .85 & .3616203 & 0 & 1 \\
\hline leverage & 40 & .3273333 & .3143698 & .000094 & .9660961 \\
Lnsize & 40 & 13.16026 & .5368664 & 12.13965 & 13.99274 \\
Firmsage & 40 & 10.6 & 6.171897 & 5 & 27
\end{tabular}

In the table above, you can see the mean, standard deviation, maximum and minimum value of each variable used in this study. For LLP total residual which is earnings management, the average value is 0.18 , for ceo photos which is a proxy for earnings management the average value is 4.3 , ceo age has an average of 52.52 , ceo tenure or long ceo work has an average value of Average 2.25, gender of CEO has an average of 0.85 , leverage has an average of 0.32 , firm size has an average of 13.16, and company age has an average value of 10.6

Table 2.2 Correlation

\begin{tabular}{r|rrrrrrrr} 
& \multicolumn{1}{|c}{ LLPTot d CEOPhoto } & CE0age CEOten e CE0gen r leverage & Lnsize Firmsage \\
\hline LLPTotalPr d & 1.0000 & & & & & & & \\
CEOPhoto & -0.4368 & 1.0000 & & & & & & \\
CE0age & 0.0953 & -0.0283 & 1.0000 & & & & & \\
CE0tenure & -0.1298 & -0.0142 & 0.3963 & 1.0000 & & & & \\
CE0gender & 0.1540 & 0.3157 & -0.0598 & -0.0504 & 1.0000 & & & \\
leverage & -0.1520 & -0.2088 & 0.1544 & 0.2102 & -0.3772 & 1.0000 & & \\
Lnsize & 0.6363 & -0.3174 & 0.1390 & -0.0521 & -0.0468 & 0.0030 & 1.0000 & \\
Firmsage & 0.7792 & -0.6095 & 0.0595 & -0.2029 & 0.0069 & -0.1564 & 0.6486 & 1.0000
\end{tabular}

After testing the classical assumptions, this study is free from heteroscedasticity, multicollinearity, and 
autoceralation. This study also tested a suitable model, and a suitable model in this study was the RE (Random Effect). From the table of regression test results, it can be concluded that the main variable in this study, namely CEO narcissism, has no effect on earnings management. The coefficient of multiple determination in this study is 0.66 , which means that the independent variable can explain the dependent variable by $66 \%$, and the rest is explained by other variables.

Tabel 2.3 Result

\begin{tabular}{|c|c|c|c|c|c|c|}
\hline Source & ss & $d f$ & MS & \multirow{3}{*}{\multicolumn{2}{|c|}{$\begin{array}{l}\text { Number of obs } \\
F(7,32) \\
\text { Prob }>F \\
\text { R-squared }\end{array}$}} & \multirow{2}{*}{$\begin{array}{r}40 \\
9.11 \\
0.0000\end{array}$} \\
\hline Made 2 & $1.2667 \mathrm{e}+26$ & 7 & $1.8096 e+25$ & & & \\
\hline Residual & $6.3529 \mathrm{e}+25$ & 32 & $1.9853 e+24$ & & & 0.6660 \\
\hline Total & $1.9020 e+20$ & 39 & $4.8769 e+24$ & Root & MSE & $1.4 e+12$ \\
\hline LLPTotalPr d & Coef. & Std. Err. & $\mathrm{t}$ & $P>|t|$ & {$[95 \%$ Conf } & . Interval] \\
\hline CEOPhoto & $-1.85 e+11$ & $3.97 e+11$ & -0.47 & 0.643 & $-9.94 e+11$ & $6.23 e+11$ \\
\hline CEOage & $1.98 \mathrm{e}+10$ & $5.55 e+10$ & 0.36 & 0.724 & $-9.33 \mathrm{e}+10$ & $1.33 e+11$ \\
\hline CEotenure & $-6.86 e+09$ & $1.24 \mathrm{e}+11$ & -0.06 & 0.956 & $-2.59 \mathrm{e}+11$ & $2.45 e+11$ \\
\hline CEOgender & $1.10 \mathrm{e}+12$ & $7.12 \mathrm{e}+11$ & 1.55 & 0.132 & $-3.49 \mathrm{e}+11$ & $2.55 e+12$ \\
\hline leverage & $-1.12 e+11$ & $8.43 e+11$ & -0.13 & 0.895 & $-1.83 e+12$ & $1.61 \mathrm{e}+12$ \\
\hline Lnsize & $1.02 \mathrm{e}+12$ & $5.76 \mathrm{e}+11$ & 1.77 & 0.086 & $-1.51 \mathrm{e}+11$ & $2.19 e+12$ \\
\hline Firmsage & $2.03 e+11$ & $6.71 e+10$ & 3.02 & 0.005 & $6.62 e+10$ & $3.40 e+11$ \\
\hline - cons & $-1.67 \mathrm{e}+13$ & $7.34 \mathrm{e}+12$ & -2.28 & 0.030 & $-3.17 e+13$ & $-1.76 e+12$ \\
\hline
\end{tabular}

$\mathrm{R} 2$ in the table is 0.66 , this means that the independent variable is able to explain the dependent variable by $66 \%$, and the rest is explained by other variables. The main variables and control variables in this study have no effect or no significant results.

\section{CONCLUSION}

The results of this study indicate that the CEO narcissism variable has no effect on earnings management in Islamic banking. This is contrary to the upper echelon theory, which states that the psychological aspects of the CEO will affect the outcomes of the company. The absence of influence between variables in this study may be due to the limited number of observations, limitations in the measurement method for CEO narcissism and perhaps for the context of Islamic banking there are other variables that need to be considered.

\section{IMPLICATIONS/LIMITATIONS AND SUGGESTIONS FOR FURTHER RESEARCH}

This study aims to see the influence of the psychological aspects of the CEO as seen from the CEO's narcissism on the outcomes of the company, namely its relation to earnings management in the company. Based on the upper echelon theory, the psychological aspects of the CEO will influence the decisions he will make, including the level of earnings management in the company. It is hoped that this research will have implications for companies to take into account the psychological aspects that exist in the CEO before the appointment of the CEO, besides this research is also expected to enrich existing research in the area of Islamic banking by taking into account the psychological aspects of the CEO. The limitation in this study is that it relates to the number of samples used, which is only in Islamic banking in Indonesia and only for 4 periods, for further research it can expand the existing sample using Asian scope for example and with a longer time period. Related to the limitations of the research there is also the measurement of CEO narcissism, for further research, other indicators can be used.

\section{References}

[1] H. Mersni and H. Ben Othman, "The impact of corporate governance mechanisms on earnings management in Islamic banks in the Middle East region," J. Islam. Account. Bus. Res., vol. 7, no. 4, pp. 318348, 2016, doi: 10.1108/JIABR-11-2014-0039.

[2] F. Buchholz, R. Jaeschke, K. Lopatta, and K. Maas, "The use of optimistic tone by narcissistic CEOs," Accounting, Audit. Account. J., vol. 31, no. 2, pp. 531-562, 2018, doi: 10.1108/AAAJ-11-2015-2292.

[3] C. Ham, N. Seybert, and S. Wang, "Narcissism is a bad sign: CEO signature size, investment, and performance," Rev. Account. Stud., vol. 23, no. 1, pp. 234-264, 2018, doi: 10.1007/s11142-017-9427-x. 
[4] R. Abdul Rahman, N. Hj Omar, A. Rahman, and R. Muda, "Islamic ethical values of corporate top leadership and real earnings management," Int. J. Law Manag., vol. 60, no. 3, pp. 869-884, 2018, doi: 10.1108/IJLMA-03-2017-0029.

[5] D. H. Zhu and G. Chen, "CEO Narcissism and the Impact of Prior Board Experience on Corporate Strategy,” Adm. Sci. Q., vol. 60, no. 1, pp. 31-65, 2015, doi: 10.1177/0001839214554989.

[6] A. Chatterjee, "It's All About Me : Narcissistic CEOs and Their Effects on Company Strategy and Performance," Adm. Sci. Q., pp. 1-62, 2006.

[7] A. Rijsenbilt, CEO Narcissism Measurement and Impact. 2011.

[8] K. J. Olsen, K. K. Dworkis, and S. Mark Young, "CEO narcissism and accounting: A picture of profits,” J. Manag. Account. Res., vol. 26, no. 2, pp. 243-267, 2013, doi: 10.2308/jmar-50638.

[9] N. Boulila Taktak and I. Mbarki, "Board characteristics, external auditing quality and earnings management," J. Account. Emerg. Econ., vol. 4, no. 1, pp. 79-96, 2014, doi: 10.1108/jaee-10-2011-0046.

[10] F. M. Hamdi and M. A. Zarai, "Corporate Governance Practices and Earnings Management in Islamic Banking Institutions,” Res. J. Financ. Account., vol. 5, no. 9, pp. 81-97, 2014.

[11] F. Buchholz, K. Lopatta, and K. Maas, "The Deliberate Engagement of Narcissistic CEOs in Earnings Management," J. Bus. Ethics, no. 0123456789, 2019, doi: 10.1007/s10551-019-04176-X.

[12] D. Olson and T. A. Zoubi, "The determinants of loan loss and allowances for MENA banks: Simultaneous equation and three-stage approaches," J. Islam. Account. Bus. Res., vol. 5, no. 1, pp. 98-120, 2014, doi: 10.1108/JIABR-07-2013-0027. 